\title{
Microbial Community Structure Driven by a Volcanic Gradient in Glaciers of the Antarctic Archipelago South Shetland
}

\author{
Eva García-Lopez, Sandra Serrano, Miguel Angel Calvo, Sonia Peña Perez, Silvia Sanchez-Casanova, \\ Laura García-Descalzo and Cristina Cid *iD
}

check for updates

Citation: García-Lopez, E.; Serrano, S.; Calvo, M.A.; Peña Perez, S.; Sanchez-Casanova, S.; GarcíaDescalzo, L.; Cid, C. Microbial Community Structure Driven by a Volcanic Gradient in Glaciers of the Antarctic Archipelago South Shetland. Microorganisms 2021, 9, 392. https://doi.org/10.3390/ microorganisms 9020392

\section{Academic Editor:}

Angelina Lo Giudice

Received: 18 January 2021

Accepted: 10 February 2021

Published: 14 February 2021

Publisher's Note: MDPI stays neutral with regard to jurisdictional claims in published maps and institutional affiliations.

Copyright: (c) 2021 by the authors. Licensee MDPI, Basel, Switzerland. This article is an open access article distributed under the terms and conditions of the Creative Commons Attribution (CC BY) license (https:/ / creativecommons.org/licenses/by/ $4.0 /)$.
Molecular Evolution Department, Centro de Astrobiologia (CSIC-INTA), Torrejón de Ardoz, 28850 Madrid, Spain; garcialoe@inta.es or garciale@cab.inta-csic.es (E.G.-L.); sandra.se.ho@gmail.com (S.S.); miguel.calvo53@gmail.com (M.A.C.); soniapenaperez@gmail.com (S.P.P.); silviasanchez1@hotmail.com (S.S.-C.); laura_garcia_descalzo@hotmail.com (L.G.-D.)

* Correspondence: cidsc@inta.es; Tel.: +34-91-520-5455
Abstract: It has been demonstrated that the englacial ecosystem in volcanic environments is inhabited by active bacteria. To know whether this result could be extrapolated to other Antarctic glaciers and to study the populations of microeukaryotes in addition to those of bacteria, a study was performed using ice samples from eight glaciers in the South Shetland archipelago. The identification of microbial communities of bacteria and microeukaryotes using 16S rRNA and 18S rRNA high throughput sequencing showed a great diversity when compared with microbiomes of other Antarctic glaciers or frozen deserts. Even the composition of the microbial communities identified in the glaciers from the same island was different, which may be due to the isolation of microbial clusters within the ice. A gradient in the abundance and diversity of the microbial communities from the volcano (west to the east) was observed. Additionally, a significant correlation was found between the chemical conditions of the ice samples and the composition of the prokaryotic populations inhabiting them along the volcanic gradient. The bacteria that participate in the sulfur cycle were those that best fit this trend. Furthermore, on the eastern island, a clear influence of human contamination was observed on the glacier microbiome.

Keywords: cryosphere microbiome; 16S/18S rRNA high throughput sequencing; glacier; biodiversity; ecology; Antarctica; biogeochemistry; astrobiology

\section{Introduction}

The cryosphere is experiencing drastic changes due to its high sensitivity to global warming. The consequences of these changes are shown at many levels. For example, effects of climatic change on vascular plants and lichens have been recently described [1,2]. Taking into account that microorganisms are the base of trophic webs, their changes affect the entire ecosystem. Both abiotic (i.e., natural forces, volcanic eruptions) and biotic factors (i.e., human presence, animal and plant populations, etc.) may positively or negatively feedback these effects. The absence of detailed knowledge of the prokaryotic diversity in poles is a major omission, taking into account the prokaryotes' numerical abundance and their importance in biogeochemical cycles. The South Shetland archipelago is an excellent example of a polar ecosystem to expand our knowledge of glacier microbiomes and how environmental changes affect them.

Glaciers are a fundamental part of the cryosphere. Recent applications of molecular genetics to microbial communities of Antarctic glaciers have rejected the belief that Antarctic glaciers host extremely limited microbial diversity. On the contrary, they not only contain a great diversity of microorganisms, but also new mechanisms of adaptation to the environment since selection acts in them with a special intensity. These features make these ecosystems unique and interesting for the study and protection of biological heritage. It is important to investigate how microbial patterns are altered and how these changes in turn 
affect the climate because microorganisms are essential components of food chains and are dominant primary producers. Moreover, these microorganisms can provide important data on the thermodynamic limits of life, which may be applicable in other disciplines such as astrobiology [3].

Among glaciers that have been drilled to study microbial populations, some examples can be cited in Antarctica [4,5], in the Arctic region in Greenland [6,7] and Alaska [8], and in the Tibetan plateau [9]. Three ecological units have been defined as microbial habitats on, within, and beneath glaciers: the supraglacial, englacial, and subglacial ecosystems [10,11].

The upper stratum (snow, surface ice, and cryoconite holes), well oxygenated and illuminated by the sun, is predominantly populated by photoautotrophic microorganisms like cyanobacteria and microalgae. When it snows, snowflakes draw bacteria from the air. These upper microorganisms colonize the inner part of the glacier through small channels. In the inner layers, in which dust particles and sand are accumulated, the population density increases. On icy surfaces, small cavities are formed on ice as a result of the deposition of cryoconite, i.e., a mixture of organic and inorganic dark particles which absorb sunlight and cause ice melting. These cryoconite holes have been widely studied because of their highly diverse and active bacterial populations [12,13].

The subglacial ecosystem is generated as a result of the friction of the ice on the rocks, creating thinner material. These fragments contain minerals and organic sedimentary carbon which combined with subglacial water creates niches optimal for microbial life. Over time, the liquid water beneath the layers of ice can form streams and lakes. Few studies have sampled subglacial environments given the challenges associated with the access to these places, but several species of archaea, bacteria, and fungi have been found. Most are chemoautotrophs which feed of minerals from rocks and soil.

Between these two ecosystems there is a hidden englacial ecosystem, much less studied. It had always been considered uninhabited or inhabited by dormant microorganisms dragged from the upper layers. Recently we have demonstrated that the englacial ecosystem is populated by microorganisms that are also metabolically active [14]. It has been shown that, since the mobility of microorganisms within the ice is nearly impossible, there is communication between microorganisms through molecules that act as regulators of response, production of antibiotics, control of oxidative stress, and reaction to chemical substances [14].

However, these results have been obtained in the glacier of a volcanic island, which makes us question if these characteristics can be extrapolated to other glaciers. To verify this, a study has been done in a transect along eight glaciers, starting from the volcano in Deception Island and heading east to the archipelago South Shetland (Figure 1).

Volcanic activity is one of the natural phenomena with the highest impact on the diverse Earth's system constituents. The area affected by an eruption can reach up to tens of thousands of $\mathrm{km}^{2}$ [15]. Some of the most relevant consequences include climate effects due to the injection of solid particles and gases into the stratosphere, changes in the temperature and composition of water sources, variations of glaciers due to the deposition of the volcanic material and instantaneous destruction of fauna and flora with the corresponding impact on the ecosystems. In Antarctica, some volcanoes have experienced activity recently, Deception Island being among the most active ones, with various eruptions in the last centuries. Currently, as a result of the successive volcanic explosions that took place on Deception Island in 1967, 1969, and 1970, volcanic remains of lava and other pyroclastic materials are deposited into the glacial ice, forming a gradient from Deception Island to the rest of the archipelago [16]. Volcanic ash deposits are extremely short-lived due to their immediate reworking by water and wind. However, in Antarctica, these materials are embedded in glacial ice and transferred to the environment over the years. These volcanic remains significantly modulate the composition of the glacier ice and may have a dominant role in shaping microbial communities. 

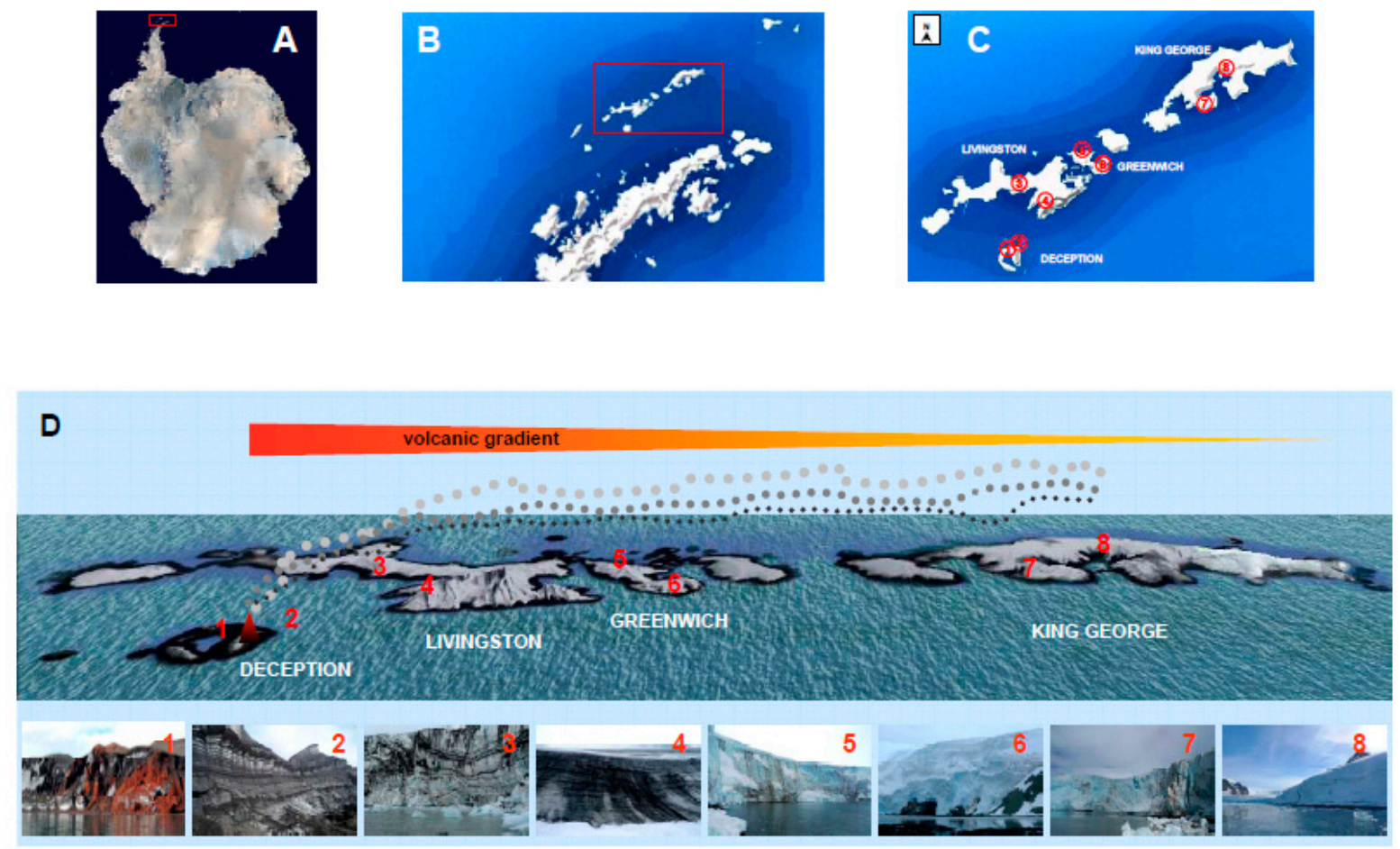

Figure 1. Location of sampling sites in South Shetland Islands, Antarctica. Satellite photographs of Antarctic continent (A) and Antarctic Peninsula (B) with South Shetland Islands boxed (ESA copyright-CC BY-SA IGO3.0; https:/ / creativecommons. org/licenses/by-sa/3.0/igo/). (C) Map of Deception, Livingston, Greenwich, and King George Islands indicating the studied glaciers. (D) Volcanic gradient and setting of samples collected at glaciers: 1 Rojo; 2 Macaroni; 3 Johnson; 4 Hurd; 5 Quito; 6 Traub; 7 Ecology; 8 Machu Picchu. Ash and lava embedded in glacial ice can be observed along the gradient in the lower images.

Other factors that can affect microbial populations are animal and human presence. Historically, human contamination in Antarctica has occurred because of explorers, fishers, whalers and more recently, scientific researchers, station support personnel, and commercial and private tourists [17]. It has been reported that human sewage pollution of aquatic environments can increase nutrient load, change $\mathrm{pH}$, temperature, and turbidity, lower dissolved oxygen availability, and contaminate the environment with diverse microorganisms $[17,18]$. All these factors can alter the composition of local microbial populations.

The specific aims of this study were to test the hypothesis that a gradient of temperature and mineral concentration in glacial ice would cause significant shifts in glacial microbial community composition and their metabolic capacity, taking into account that physicochemical conditions may have the dominant role in shaping microbial populations. To examine this hypothesis, the structure and diversity of glacier bacterial and microeukaryotic communities from eight representative glacier ice samples collected in four South Shetland Islands were analyzed using a molecular (high throughput rRNA gene sequencing)-based approach. Several essential questions were also addressed: (i) Are these glaciers influenced by the Deception Island volcano? (ii) Does this influence diminish with distance? (iii) Are there other factors that influence the diversity of microbial populations (i.e., human or animal pressure)? Together, these studies aimed to improve our understanding of the diversity and possible origins, functions, and trophic interactions of glacier microbiomes.

\section{Materials and Methods}

\subsection{Sites and Sample Collection}

Glacial ice samples were collected at eight sites on the Antarctic Archipelago South Shetland glacier fronts to have access to the englacial zone. Samples were named: Rojo 
(ROJ) and Macaroni (MAC) glaciers in Deception Island, Johnson (JOH) and Hurd (HUR) glaciers in Livingston Island, Quito (QUI) and Traub (TRA) glaciers in Greenwich Island, and Ecology (ECO) and Machu Pichu (MPI) glaciers in King George Island, in February 2015 (Figure 1).

GPS coordinates of the sampling points are detailed in Table 1. Ice samples were obtained by removing $20-30 \mathrm{~cm}$ of surface debris and extracted by drilling with a Mark II Kovacs Core System. One horizontal ice core of $9 \mathrm{~cm} \times 1 \mathrm{~m}$ was extracted at each glacier. Only the innermost end of the horizontal core $(60 \mathrm{~cm})$ was considered for the analysis (20 cm for each sample approximately).

Table 1. Glacier coordinates.

\begin{tabular}{|c|c|c|c|c|c|c|c|c|}
\hline \multirow{2}{*}{$\begin{array}{l}\text { ISLAND } \\
\text { GLACIER }\end{array}$} & \multicolumn{2}{|c|}{ Deception } & \multicolumn{2}{|c|}{ Livingston } & \multicolumn{2}{|c|}{ Greenwich } & \multicolumn{2}{|c|}{ King George } \\
\hline & $\mathrm{ROJ}^{\mathrm{a}}$ & MAC & $\mathrm{JOH}$ & HUR & QUI & TRA & ECO & MPI \\
\hline $\begin{array}{l}\text { GPS Coor- } \\
\text { dinates }\end{array}$ & $\begin{array}{l}62^{\circ} 57^{\prime} 30.5^{\prime} \mathrm{S} \\
60^{\circ} 35^{\prime} 55.6^{\prime \prime} \mathrm{W}\end{array}$ & $\begin{array}{l}62^{\circ} 54^{\prime} 09.2^{\prime \prime} \mathrm{S} \\
60^{\circ} 32^{\prime} 03.6^{\prime \prime} \mathrm{W}\end{array}$ & $\begin{array}{l}62^{\circ} 38^{\prime} 60.0^{\prime \prime} \mathrm{S} \\
60^{\circ} 21^{\prime} 00.0^{\prime \prime} \mathrm{W}\end{array}$ & $\begin{array}{l}62^{\circ} 41^{\prime} 0.5^{\prime \prime} \mathrm{S} \\
60^{\circ} 20^{\prime} 74^{\prime \prime} \mathrm{W}\end{array}$ & $\begin{array}{l}62^{\circ} 27^{\prime} 00.0^{\prime \prime} \mathrm{S} \\
59^{\circ} 45^{\prime} 00.0^{\prime \prime} \mathrm{W}\end{array}$ & $\begin{array}{l}62^{\circ} 27^{\prime} 59.7^{\prime \prime} \mathrm{S} \\
59^{\circ} 45^{\prime} 23.8^{\prime \prime} \mathrm{W}\end{array}$ & $\begin{array}{l}62^{\circ} 09^{\prime} 60.0^{\prime \prime} \mathrm{S} \\
58^{\circ} 28^{\prime} 00.0^{\prime \prime} \mathrm{W}\end{array}$ & $\begin{array}{r}62^{\circ} 6^{\prime} 0^{\prime \prime} \mathrm{S} \\
58^{\circ} 28^{\prime} 0^{\prime \prime} \mathrm{W}\end{array}$ \\
\hline
\end{tabular}

a Sample name: Rojo (ROJ), Macaroni (MAC), Johnson (JOH), Hurd (HUR), Quito (QUI), Traub (TRA), Ecology (ECO), Machu Pichu (MPI).

Three sampling replicates were collected from each glacier. Samples were wrapped in sterile plastic bags and stored at $-20^{\circ} \mathrm{C}$ until analyzing in the laboratory at the Centre for Astrobiology, Madrid, Spain. Samples were decontaminated following the methods described in previous studies $[14,19]$. Each sample was thawed in sterile containers at $4{ }^{\circ} \mathrm{C}(1000 \mathrm{~mL})$, and separately used for all the analysis. All procedures were performed by using bleach-sterilized work areas, a UV-irradiated laminar flow hood, ethanol-sterilized tools, and sterilized gloves. To control for laboratory contamination, 1 liter of MilliQ rinse water was subjected to equal analytical procedures.

\subsection{Chemical Analysis of Meltwater}

Meltwater chemistry was analyzed to examine changes along the volcanic gradient. Analyses included in situ $\mathrm{pH}$, temperature, and chemical composition of ice samples. Basic measurements of the physical and chemical parameters of meltwater were made with a temperature-calibrated $\mathrm{pH}$ and conductivity meter (WTW, Weilheim, Germany). Assays for $\mathrm{NH}_{4}{ }^{+}, \mathrm{NO}^{2-}, \mathrm{NO}^{3-}$, total dissolved nitrogen (TDN), soluble reactive phosphorus (SRP) and dissolved organic carbon (DOC) from each sample were performed as described elsewhere [20] by ion chromatography in an 861 Advance Compact IC system (Metrohm AG, Herisau, Switzerland). The measurements of major, minor, and trace elements (Ag, $\mathrm{Al}$, As, B, Ba, Be, Bi, Br, C, Ca, Cd, Cl, Co, Cr, Cu, Fe, Ga, Ge, K, Li, Mg, Mn, Mo, Na, Ni, P, $\mathrm{Pb}, \mathrm{Rb}, \mathrm{S}, \mathrm{Sc}, \mathrm{Se}, \mathrm{Sr}, \mathrm{Ti}, \mathrm{V}, \mathrm{Y}, \mathrm{Zn}$, and $\mathrm{Zr}$ ) (Table S1) were performed by inductively coupled plasma-mass spectrometry (ICP-MS) on a PerkinElmer ELAN9000 ICP-MS quadrupole spectrometer as in [14]. The samples were introduced into the ICP-MS via a RytonTM crossflow nebulizer (PerkinElmer, Waltham, MA, USA), Scott spray chamber (PerkinElmer), and Cetac ASX-510 autosampler (Omaha, NE, USA).

\subsection{DNA Extraction and Sequencing}

Approximately $500 \mathrm{~mL}$ of each frozen sample was melted at $4{ }^{\circ} \mathrm{C}$ and filtered through a $0.22 \mu \mathrm{m}$ filter (Millipore). Extraction procedures were identical for all samples. DNA concentration was determined using a Nanodrop 2000p. Then, Illumina sequencing was applied to each sampling replicate. Purified DNA was quantified and 1ng of input DNA was used in a first PCR of 20 cycles with $\mathrm{Q} 5^{\circledR}$ Hot Start High-Fidelity DNA Polymerase (New England Biolabs) in the presence of 100nM primers of the regions V3 and V4 of the 16S rRNA gene, or of the region V4 and V5 region of the 18S rRNA gene as previously reported [21,22]. Primers sequences were: V3-V4 (Forward ACACTGACGACATGG TTCTACACCTACGGGNGGCWGCAG, Reverse TACGGTACGACTTGGTCTGTACHV GGGTATCTAATCC); V4-V5 (Forward GCCCAVCYGCGGTAAY, Reverse CCGT- 
CAATTHCTTYAART). After the first PCR, a second PCR of 15 cycles was carried out with Q5 ${ }^{\circledR}$ Hot Start High-Fidelity DNA Polymerase (New England Biolabs) in the presence of $400 \mathrm{nM}$ of primers Forward AATGTACGCGACCACCGAGATCTACACTGACGACATGGTTCTACA and Reverse CAAGCAGAAGACGGCATACGAGAT [10 nucleotides barcode] TACGGTAGCAGAGACTTGGTCT of the Access Array Barcode Library for Illumina Sequencers (Fluidigm). Amplicons were validated and quantified by Bioanalyzer and an equimolecular pool was purified using AMPure beads and titrated by quantitative PCR using the Kapa-SYBR FAST qPCR kit for LightCycler 480 and a reference standard for quantification. The pool of amplicons were denatured prior to being seeded on a flowcell at a density of $10 \mathrm{pM}$, where clusters were formed and sequenced using a MiSeq Reagent Kit v3, in a $2 \times 300$ pair-end sequencing run on a MiSeq sequencer to obtain 100,000 reads per sample approximately.

Sequencing data were analyzed with UCHIME [23], to identify and remove chimeric reads, and classified to eliminate those that could be considered contaminants. Sequence reads were grouped according to their taxonomic classification using the BaseSpace platform and the Greengenes $16 \mathrm{~S}$ rRNA database. In general, this strategy allowed the classification of sequences into taxonomic categories that were never lower than genus rank. The correspondence of operational taxonomic units (OTUs) to species was assessed considering a 97\% identity threshold. Analytic Rarefaction 1.3 software (https:/ / strata.uga.edu/software) (accessed on 22 November 2020) was used to perform rarefaction analysis [24,25]. It showed that, at $3 \%$ sequence divergence, rarefaction curves nearly reached saturation, indicating that samples contained almost all the diversity at this genetic distance (Figure S1).

\subsection{Statistical Analysis}

Statistical differences in the number of clones and the number of OTUs were studied by the ANOVA test using GraphPad Prism 6.0 software. Data of OTUs and clones are media values of three sampling replicates. Effects of environmental variables on the community composition were investigated by a combination of analysis (DCA, detrended correspondence analysis and CCA, canonical correspondence analysis) developed with CANOCO 5 software [26]. For statistical analysis, Monte Carlo permutation tests with 500 permutations were used.

\subsection{Nucleotide Sequence Accession Numbers}

Sequences obtained from $16 \mathrm{~S}$ rRNA sequencing were deposited in NCBI Short Read Archive (SRA) (accession numbers SAMN14863991, SAMN14868361, SAMN14868400, SAMN14868414, SAMN14868429, SAMN14868542, SAMN14868580, and SAMN14868598). Sequences obtained from $18 \mathrm{~S}$ rRNA sequencing were deposited in NCBI SRA (accession numbers SAMN14868636, SAMN14868654, SAMN14868683, SAMN14868702, SAMN14868717, SAMN14868740, SAMN14868844, and SAMN14868902).

\section{Results and Discussion}

\subsection{General Characteristics of the Ice Samples and Chemical Properties}

The South Shetland glaciers studied encompassed a high degree of physicochemical heterogeneity, although the $\mathrm{pH}$ values were similar in all the sampling points (Table 2). Temperature measurements in sampling sites showed a significant increase from west to east along the archipelago. 
Table 2. Geochemical properties and chemical analysis of soluble nutrients in the meltwater.

\begin{tabular}{|c|c|c|c|c|c|c|c|c|}
\hline \multirow{2}{*}{$\begin{array}{c}\text { ISLAND } \\
\text { GLACIER }\end{array}$} & \multicolumn{2}{|c|}{ Deception } & \multicolumn{2}{|c|}{ Livingston } & \multicolumn{2}{|c|}{ Greenwich } & \multicolumn{2}{|c|}{ King George } \\
\hline & $\mathrm{ROJ}^{\mathrm{e}}$ & MAC & JOH & HUR & QUI & TRA & ECO & MPI \\
\hline $\mathrm{DGV}^{\mathrm{a}}(\mathrm{Km})$ & 1.1 & 2.1 & 3.5 & 36.8 & 68 & 68.5 & 136 & 142 \\
\hline $\mathrm{T}^{\mathrm{a}}\left({ }^{\circ} \mathrm{C}\right)$ & -0.5 & 0 & -0.1 & -3 & -5 & -5.1 & -5.2 & -5.3 \\
\hline $\mathrm{pH}$ & 5.5 & 4.5 & 4.5 & 5.0 & 5.0 & 5.0 & 5.5 & 4.5 \\
\hline $\mathrm{NH}_{4}^{+}(\mu \mathrm{M})$ & $2.21(0.09)$ & $1.87(0.25)$ & $1.52(0.14)$ & $1.32(0.08)$ & $1.20(0.25)$ & $1.01(0.18)$ & $60.04(4.21)$ & $55.04(2.31)$ \\
\hline $\mathrm{NO}_{2}{ }^{-}(\mu \mathrm{M})$ & $3.99(0.29)$ & $3.01(0.29)$ & $4.21(0.23)$ & $5.14(0.21)$ & $\mathrm{BD}^{\mathrm{f}}$ & $\mathrm{BD}$ & $55.87(5.06)$ & $59.11(3.66)$ \\
\hline $\mathrm{NO}_{3}-(\mu \mathrm{M})$ & $18.01(0.99)$ & $6.52(0.44)$ & $7.01(0.11)$ & $7.41(0.17)$ & $4.25(0.24)$ & $3.02(0.35)$ & $90.81(6.33)$ & $99.87(5.43)$ \\
\hline $\mathrm{TDN}^{\mathrm{b}}$ & $91.35(0.12)$ & $188.04(8.32)$ & $110.32(6.33)$ & $100.18(7.54)$ & $90.24(3.22)$ & $77.01(4.28)$ & $122.11(6.55)$ & $100.11(2.55)$ \\
\hline $\mathrm{SRP}^{\mathrm{c}}$ & $0.88(0.14)$ & $0.42(0.12)$ & $0.54(0.14)$ & $0.66(0.01)$ & $0.41(0.12)$ & $0.51(0.01)$ & $1.38(0.01)$ & $1.24(0.01)$ \\
\hline DOC $^{d}$ & $44.32(5.21)$ & $77.21(8.45)$ & $56.14(5.34)$ & $40.28(8.22)$ & $55.01(8.32)$ & $41.37(6.37)$ & $111.12(5.22)$ & $120.22(5.12)$ \\
\hline
\end{tabular}

Concentrations are expressed in $\mu \mathrm{M}\left( \pm\right.$ SEM) of three replicates. ${ }^{a}$ DGV: Distance glacier-volcano; ${ }^{\mathrm{b}} \mathrm{TDN}$ : Total dissolved nitrogen; ${ }^{\mathrm{c}}$ SRP: Soluble reactive phosphorus; ${ }^{\mathrm{d}}$ DOC: dissolved organic carbon; ${ }^{\mathrm{e}}$ Sample name: Rojo (ROJ), Macaroni (MAC), Johnson (JOH), Hurd (HUR), Quito (QUI), Traub (TRA), Ecology (ECO), Machu Pichu (MPI); ${ }^{\mathrm{f}} \mathrm{BD}$ : below detection or $<0.3 \mu \mathrm{M}$; the highest nutrient values are marked in bold.

Among nutrients, $\mathrm{NH}_{4}{ }^{+}, \mathrm{NO}_{2}{ }^{-}, \mathrm{NO}_{3}{ }^{-}, \mathrm{TDN}, \mathrm{SRP}$, and DOC (Table 2), the highest concentrations were generally found on King George Island. If only the rest of the islands were considered, the highest concentrations were observed on Deception Island. These organic compounds could come from sewage pollution [17] on the most populated island, King George. In addition, these islands are the most inhabited by seabirds and have a significant population of penguins. The high concentrations of nitrogen compounds observed could also come from the ornitogenic soils that surround the glaciers [27].

Ash and pyroclastic material emitted by volcanoes provide some chemical elements that microorganisms can also use as nutrients (i.e., $\mathrm{C}, \mathrm{Ca}$, and $\mathrm{Fe}$ ). In addition, potentially toxic trace elements (e.g., $\mathrm{Al}, \mathrm{As}, \mathrm{Cu}, \mathrm{F}, \mathrm{Mo}, \mathrm{Ni}, \mathrm{Pb}$, and $\mathrm{Zn}$ ) are released into the environment. Chemical elements in meltwater were quantified and represented in Table S1. According to several reports, some of these elements are more involved in the geochemical impact of volcanic ash than others because of their differential mobilization in water after the volcanic eruption $[15,28]$. It has also been asserted that there are notable variations in the concentrations of the elements involved from volcano to volcano and even between eruptions of the same volcano [15]. Generally, a concentration gradient was observed in these elements, with maximum values in the most extreme islands. From Decepcion Island a descending gradient of elements of volcanic origin $(\mathrm{C}, \mathrm{Ca}, \mathrm{Cd}, \mathrm{Fe}, \mathrm{S}$, etc.) was observed. From the eastern islands, there was a westward gradient of other elements $(\mathrm{As}, \mathrm{Br}, \mathrm{Cl}, \mathrm{Na}$, etc.). The observed high values of $\mathrm{Cl}$ and $\mathrm{Na}$ could come from seawater in glaciers that are most coastal or most exposed to the sea waves.

\section{2. $16 S$ and $18 S$ rRNA Gene Clone Libraries}

The V3 and V4 regions of the 16S rRNA gene were sequenced by Illumina MiSeq (Table S2). A total of 602,053 reads were obtained which belonged to 710 OTUs spanning 28 phyla. Microorganisms mainly corresponded to the phyla Firmicutes $(29 \%)$, Proteobacteria (20\%), and Bacteroidetes (19\%) (Figure 2A). Some phyla such as Tenericutes, Chrysiogenetes, Chlorobi, and Fusobacteria were scarce. The glaciers with the highest number of different OTUs were MAC and JOH. Some of the identified OTUs such as Polaribacter, Polaromonas, Psychrobacter, Psychromonas, and Cryobacterium have been described as being typical Antarctic psychrophilic and psychrotolerant bacteria. On the contrary, microorganisms as Thermobaculum, Thermovenabulum, Thermoanaerobacterium, Thermodesulfovibrio, Thermomonas, and Caldanaerobacter were thermophilic or hyperthermophilic. Furthermore, several genera of cyanobacteria as Chroococcidiopsis capable of endolithic colonization in volcanic rocks were found [29]. 

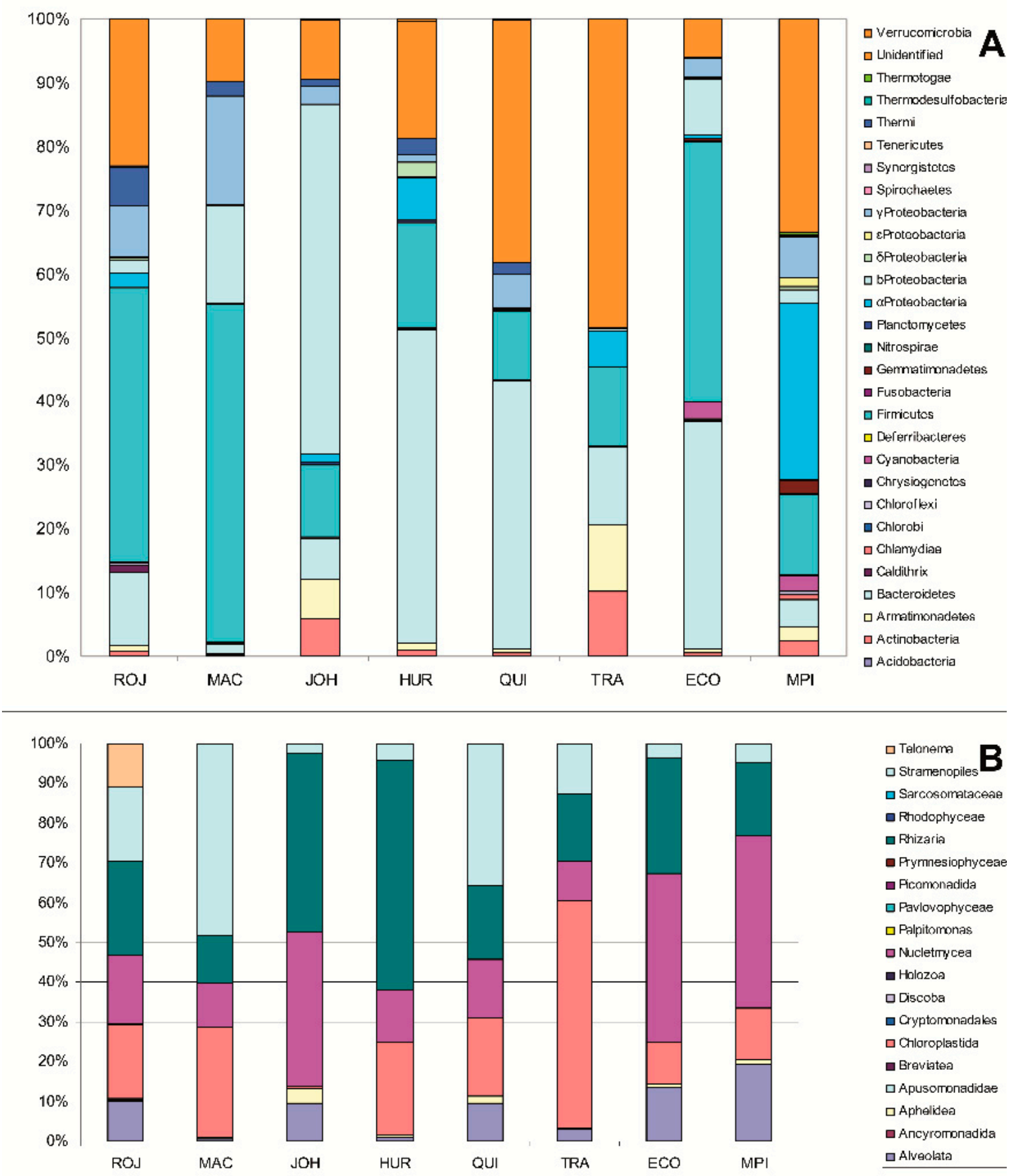

Figure 2. Composition of microbial communities. Relative abundances of major taxa of (A) bacteria and (B) microeukaryotes in the englacial ecosystem based on $16 \mathrm{~S}$ and $18 \mathrm{~S}$ rRNA gene sequencing.

Regarding the research of microeukaryotes (Table S3), amplification and sequencing of the $\mathrm{V} 9$ region of the $18 \mathrm{~S}$ rRNA gene rendered a total of 1,386,341 reads from 1248 OTUs and 20 phyla (Figure 2B). The most frequent phyla were Nucletmycea (42\%), Rhizaria (23\%), and Chloroplastida (18\%). Nucletmycea, that is, fungi had been extensively described in Antarctic soils [30], but they are not found as frequently in glacial ice [31]. We also found several genera of typical endolithic algae belonging to the class Trebouxiophyceae, widespread in the Antarctic Dry Valleys [32]. The most abundant bacterial and eukaryotic OTU in each sampling point has been represented in Table S4. 


\subsection{Differences in Community Structure among Glaciers}

In the studied South Shetland glaciers, a great diversity was observed when compared with other Antarctic glaciers [33] or with the microbiomes of the frozen deserts in the McMurdo Dry Valleys [34]. In these South Shetland glaciers, the communities of microorganisms were isolated from small isolated clusters within the ice. Even the composition of the prokaryotic populations identified in the glaciers from the same island was different (Figure 2).

In general, the number of $16 \mathrm{~S}$ rRNA sequences was higher in western glaciers than in eastern glaciers. With the number of $18 \mathrm{~S}$ rRNA sequences, the opposite trend was observed (Figure S2). Furthermore, the westernmost glaciers in the South Shetland archipelago were inhabited by psychrophilic microorganisms, but also contained bacteria characteristic of volcanic regions such as Sulfobacillus yellowstonensis [35], the most abundant bacteria in ROJ samples (Table S4). These results are probably influenced by the special conditions of Deception Island, an active volcano where glacial ice contains elevated concentrations of certain elements diffusing from geothermal sources. This suggests that active geothermal processes may serve as an additional source of trace elements, or that local physicochemical parameters promote an increase in bioavailability at Deception Island forming a special microbial community. Its fluctuating conditions include temperature gradients, oxygen levels, and multiple forms of chemical energy, such as methane, hydrogen, and hydrogen sulfide.

In the central islands, psychrophilic microorganisms were more abundant (Polaribacter, Polaromonas, and Psychrobacter) (Table S2). The eastern islands are those that suffer the greatest human pressure and their glaciers contain microorganisms typical of human (Enterobacteriaceae, Helicobacter) or animal contamination (i.e., the microeukaryote Cryptosporidium) (Tables S2 and S3) [18,36]. Figure S3 represents the abundance of some microbial species that could be related to human and animal contamination. An increasing number of reports have shown the introduction and spread of non-native plants [37], shifts of bird and seal breeding areas, and decreases in both bird and seal populations [38]. However, few analyses have been reported at a microbial level.

Some investigations have demonstrated that the composition of glacier microbiomes depends on the proximity to the sea [21]. In several Arctic coastal glaciers, the genus Hymenobacter has been described as a possible sentinel for bacterial transport between glaciers and their downstream seawaters. In these South Shetland glaciers, Hymenobacter was also identified in coastal glacier samples. Other typical marine microorganisms found in these glaciers were Marinobacter [39], Polaribacter, and Roseospira [40,41]. Examples of marine microeukaryotes identified in glacier ice include choanoflagellates, alveolates such as Trichototaxis marina and Caudiholosticha marina, and various types of stramenopiles [42,43].

\subsection{Distribution of Taxa along the Volcanic Gradient}

To study the distribution of microorganisms across all samples, a DCA was carried out taking into account the relative abundances of the microbial phyla. This analysis clustered microorganisms into two groups of bacteria and two groups of microeukaryotes. Therefore, bacteria and microeukaryotes associate in separate groups (Figure 3).

To check if there was a gradient in the microbiological composition of the glacial ice samples, several CCA in which the distance to the volcanic focus was considered were carried out. These analyses demonstrated that there was a clear correlation between the distance to the volcano and the presence of some groups of bacteria (Figure 4A). Several phyla were associated with the volcanic focus (i.e., Thermotogae), while others were grouped away from the volcano (i.e., Betaproteobacteria). This same effect could be observed when microeukaryotes data were analyzed (Figure 4B). 


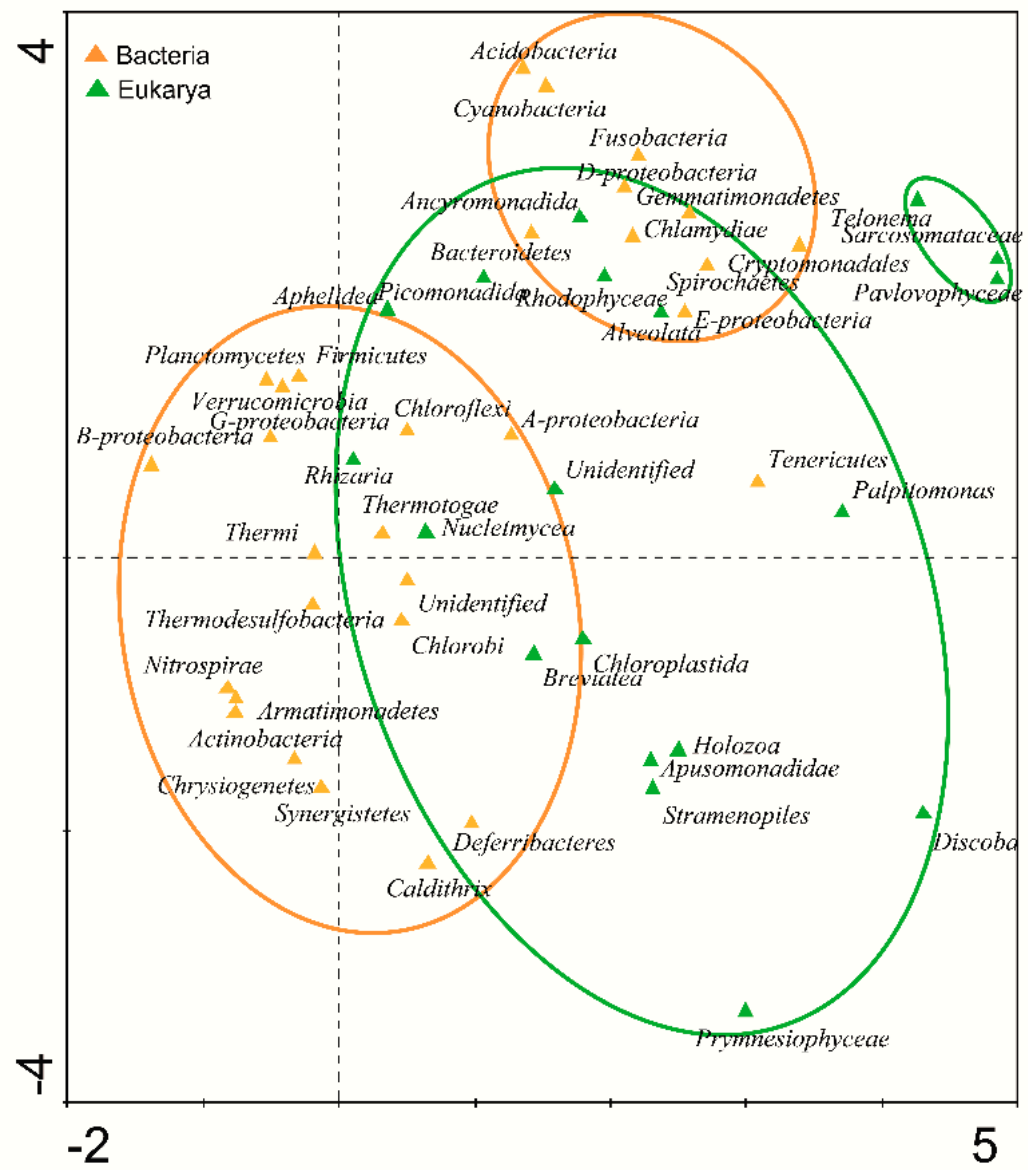

Figure 3. The relative abundances of the microbial phyla of bacteria and microeukaryotes were analyzed by detrended corresponded analysis (DCA). The diagram displays triangles that represent phyla of bacteria (orange) and microeukaryotes (green). Venn diagrams cluster and discriminate areas in which bacteria (orange diagrams) or microeukaryotes (green diagrams) are more abundant.

Then, several CCA with all nutrients $\left(\mathrm{NH}_{4}{ }^{+}, \mathrm{NO}_{2}{ }^{-}, \mathrm{NO}_{3}{ }^{-}\right.$, $\mathrm{TDN}$, and DOC) were used to estimate the proportion of the community diversity attributable to each nutrient concentration. In these analyses, arrows indicate the direction in which phyla increase in abundance [44]. Arrows that point in the same direction indicate positive correlation, perpendicular arrows indicate lack of correlation and arrows pointing in the opposite direction indicate negative correlation. According to Figure 5, several phyla of bacteria were grouped along the arrows (Figure 5A), while microeukaryotes did not follow the direction of arrows so accurately (Figure 5B). The quantification of these results, expressed by the eigenvalues (Table 3), demonstrated that both bacterial and eukaryotic populations were dependent on these nutrients. Nevertheless, the eigenvalues explained the diversity for microeukaryotes (Table 3, analysis no. 5) better than they did for bacteria (analysis no. 5).

Table 3. Summary of canonical correspondence analysis and correlations.

\begin{tabular}{|c|c|c|c|c|c|c|c|}
\hline Type of Microorganism & No. of Analysis & Type of Analysis & Variables & $\lambda 1$ & $\lambda 2$ & $\lambda 3$ & $\lambda 4$ \\
\hline \multirow{3}{*}{ Bacteria } & 1 & CCA & $\mathrm{DGV}^{\mathrm{a}}$ & 0.715 & 0.000 & 0.000 & 0.000 \\
\hline & 2 & CCA & $\mathrm{NH}_{4}^{+}, \mathrm{NO}_{2}^{-}, \mathrm{NO}_{3}^{-}, \mathrm{TDN}, \mathrm{DOC}$ & 0.794 & 0.708 & 0.795 & 0.440 \\
\hline & 3 & CCA & $\mathrm{As}, \mathrm{C}, \mathrm{Ca}, \mathrm{Cd}, \mathrm{Cl}, \mathrm{Fe}, \mathrm{K}, \mathrm{Mg}, \mathrm{Na}, \mathrm{S}$ & 0.859 & 0.752 & 0.795 & 0.814 \\
\hline \multirow{3}{*}{ Eukarya } & 4 & CCA & DGV $^{a}$ & 0.743 & 0.000 & 0.000 & 0.000 \\
\hline & 5 & CCA & $\mathrm{NH}_{4}{ }^{+}, \mathrm{NO}_{2}^{-}, \mathrm{NO}_{3}^{-}, \mathrm{TDN}, \mathrm{DOC}$ & 0.982 & 0.905 & 0.888 & 0.681 \\
\hline & 6 & CCA & As, C, Ca, Cd, $\mathrm{Cl}, \mathrm{Fe}, \mathrm{K}, \mathrm{Mg}, \mathrm{Na}, \mathrm{S}$ & 0.202 & 0.054 & 0.040 & 0.017 \\
\hline
\end{tabular}

${ }^{\text {a }}$ DGV: Distance glacier-volcano. 


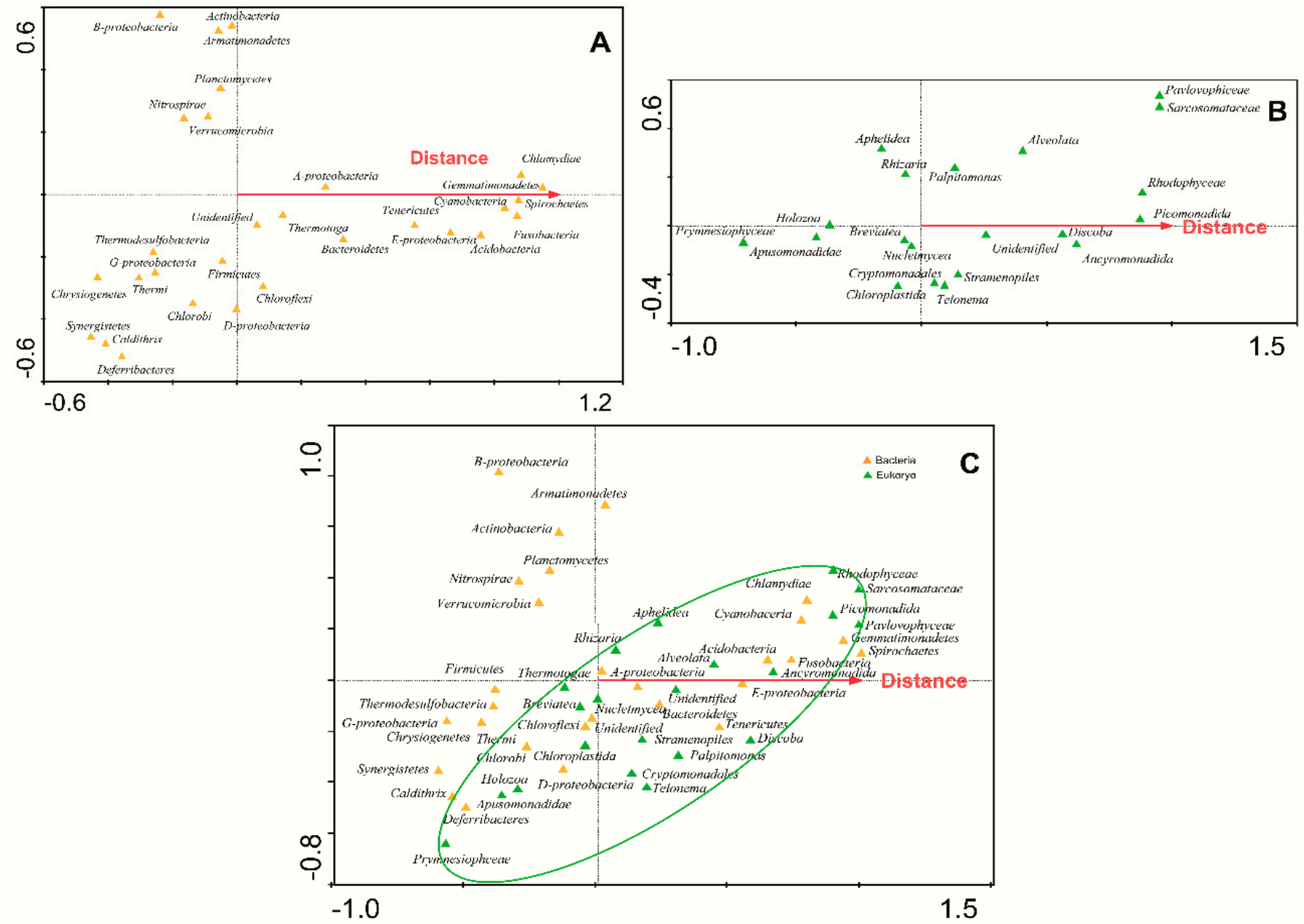

Figure 4. Canonical correspondence analysis (CCA) of the microbial phyla with respect to the distance from the volcano. CCA of phyla of bacteria (A) and microeukaryotes (B) identified in glaciers with respect to the distance from the volcano. The diagram displays triangles that represent taxonomic groups. (C) CCA of all the microbial phyla (bacteria and microeukaryotes) identified in glaciers with respect to the distance from the volcano. The diagram displays orange triangles for bacteria and green triangles for microeukaryotes. Venn diagram clusters an area in which microeukaryotes are more abundant.

When these CCA analyses were performed for the main chemical elements contained in the meltwater samples (Figure 6, Table 3), it could be shown that there was a correlation between the chemical composition of the glacial ice and the composition of the microbiomes along the volcanic gradient. According to eigenvalues, the correlation between the distribution of bacteria and the concentrations of these chemical elements was significant (Table 3, analysis no. 3). In contrast, microeukaryote populations were poorly correlated with the concentration of chemical elements (analysis no. 6). In conclusion, both volcanic chemical elements (i.e., Fe, Cd, S) and some bacterial groups (i.e., Caldithrix, Deferribacteres, Thermi, Thermodesulfobacteria, Thermotogae) follow the same volcanic gradient. It had already been reported that in Antarctica, the nutrient content in glacial ice is very low and volcanic ash contributes to its increase, favoring the massive development of some types of microorganisms [15]. 


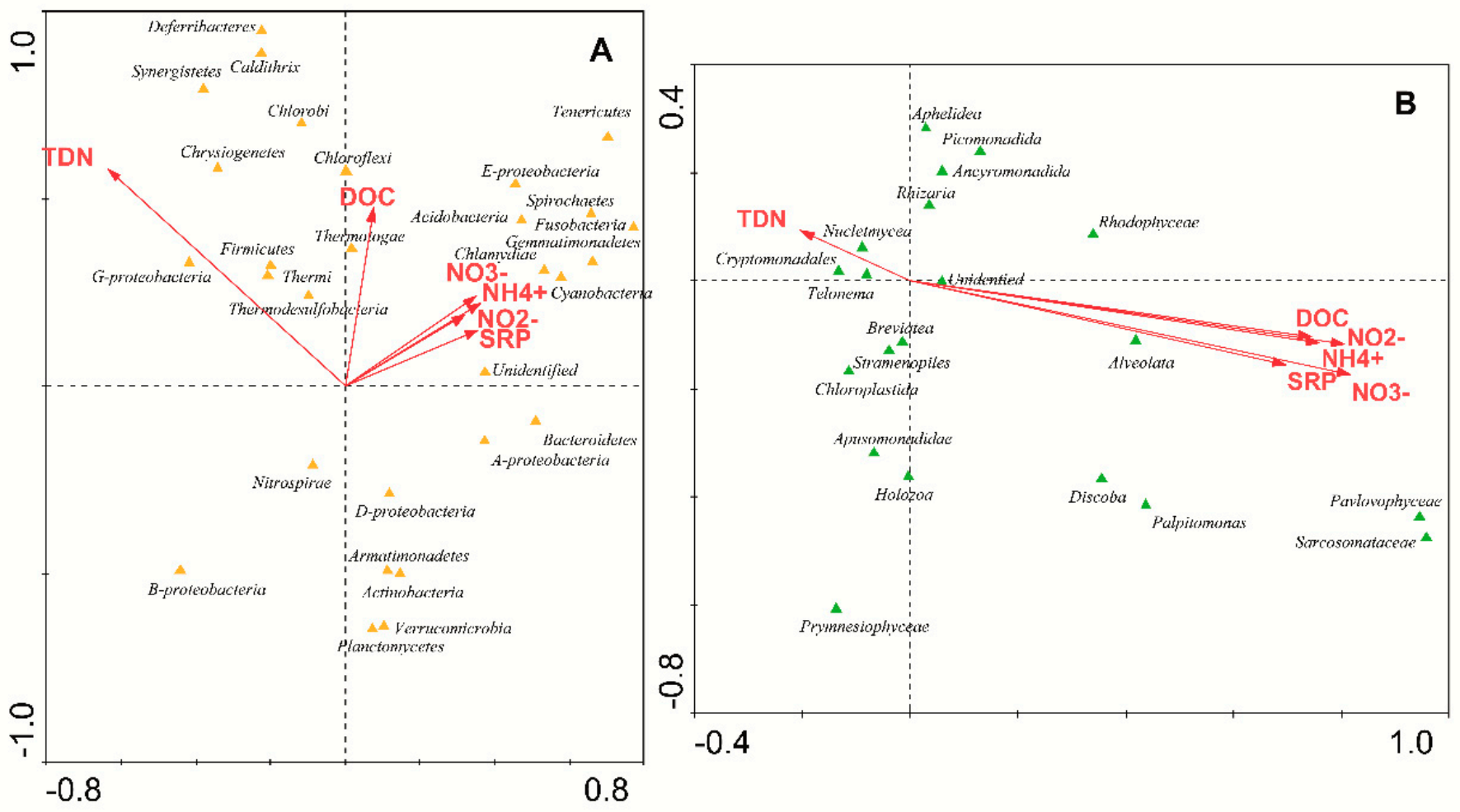

Figure 5. CCA of the microbial phyla of (A) bacteria and (B) microeukaryotes identified in glaciers with respect to the concentration of nutrients $\left(\mathrm{NH}_{4}{ }^{+}, \mathrm{NO}_{2}{ }^{-}, \mathrm{NO}_{3}{ }^{-}\right.$, total dissolved nitrogen (TDN), soluble reactive phosphorous (SRP), and dissolved organic carbon (DOC)).

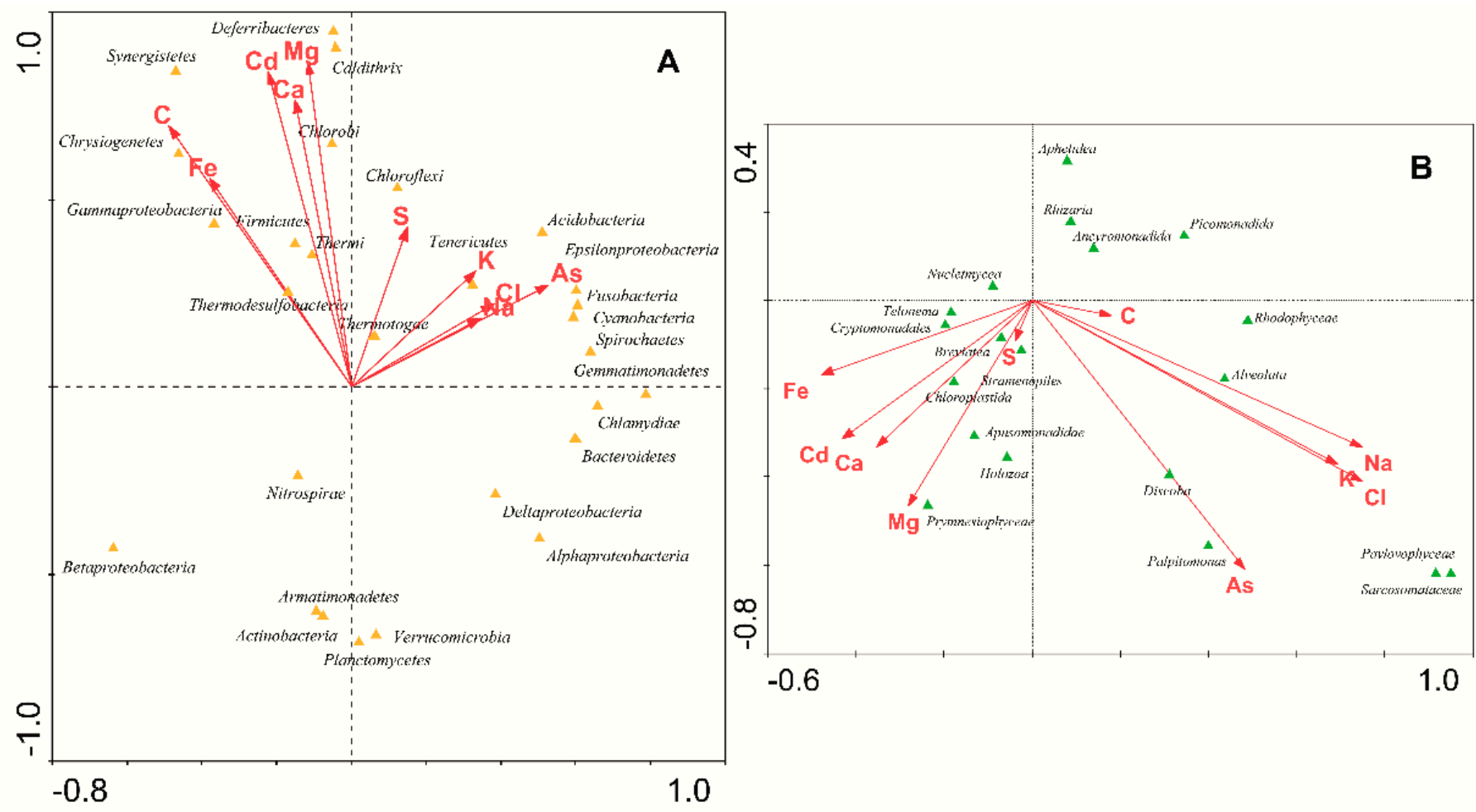

Figure 6. CCA of the microbial phyla of (A) bacteria and (B) microeukaryotes identified in glaciers with respect to the concentration of main elements (As, C, Ca, Cd, Cl, Fe, K, Mg, Na, S). 
Overall, since the diversity of bacteria was significantly correlated with the concentrations of both organic nutrients and chemical elements, it appears that bacteria were both autotrophs (photo and chemolithoautotrophs) and heterotrophs. However, eukaryotic populations were only correlated with organic nutrients, and therefore they must be photoautotrophs or heterotrophs.

\subsection{Biogeochemical Cycles Inferred from Taxonomy}

Given prokaryotes' importance in biogeochemical transformations, a deeper knowledge of their involvement in polar biogeochemical cycles is required to understand their contributions to the wider ecosystem. In our glacier samples, some key members of carbon, nitrogen, phosphorus, iron, and sulfur cycles were identified (Figure 7, Tables S2 and S3).

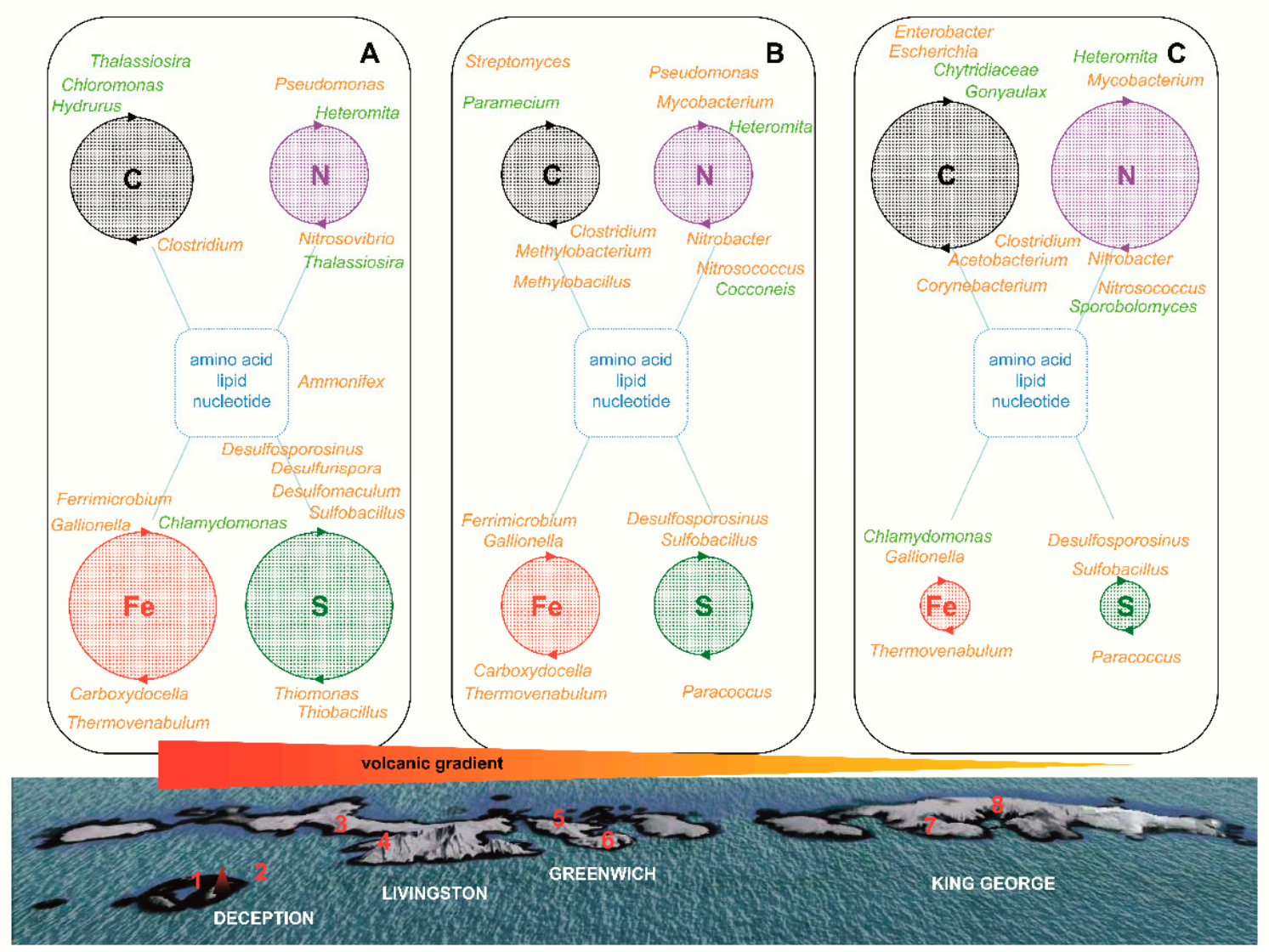

Figure 7. Insights into biogeochemical cycles based on the volcanic gradient along South Shetland glaciers. Some key members of carbon, nitrogen, iron, and sulfur cycles in glaciers were represented at the genus level (bacteria colored in orange and microeukaryotes colored in green). The size of the circles was calculated by the number of operational taxonomic units (OTUs) occurring at a frequency of more than 3\% at sample points: (A) sample points 1 and 2, (B) sample points 3 to 6 and $(\mathbf{C})$ sample points 7 and 8 .

Organic compounds in glacier ice must be biologically synthesized by $\mathrm{CO}_{2}$ fixation by phototrophs, i.e., the microeukaryotes Thalassiosira antarctica and Hydrurus foetidus identified in ROJ and MAC samples or chemolithotrophs such as Streptomyces [45,46]. In our research, we have also identified some aerobic CO oxidizers as Corynebacterium [47], especially in the eastern glaciers. Furthermore, organic compounds can be originated outside the glacier from animal, plant, or human remains. Afterward, this organic matter is degraded by considerable diversity of fungi such as Chytridiaceae sp., more abundant in the eastern islands. Several methylotrophs were identified in TRA and QUI glaciers in Greenwich Island (i.e., Methylobacterium and Methylobacillus), which can aerobically catabolize methane and many other $\mathrm{C} 1$ compounds. In the eastern glaciers, a large num- 
ber of bacteria that metabolize other organic compounds were found, probably coming from human or animal contamination; among which Enterobacteriaceae stands out (i.e., Enterobacter, Escherichia). Some acetogens, which reduce carbonate to acetate, were also identified mainly in the eastern islands samples (Acetobacterium). Among heterotroph microeukaryotes, a high diversity of alveolates was found, especially ciliates and dinoflagellates. These microorganisms (i.e., Paramecium, Gonyaulax) often feed on bacteria or contain other endosymbiotic microorganisms that synthesize vitamins or other growth factors used by the host cell [32].

Moreover, organic matter deposited by marine birds, especially penguins, accumulates giving rise to the formation of ornithogenic soils where phosphatization is the main soilforming process. This procedure greatly enhances nutrient availability, especially $\mathrm{P}$ and N. Some notable nesting zones are located in the South Shetland archipelago, especially on Deception and Barrientos islands. These two areas with ornithogenic soil are quite close to the ROJ and MAC glaciers in Deception Island [48], and QUI in Greenwich Island [27], sampling points 1, 2, and 6 respectively (Figure 7). In this type of soil, several bacterial species were identified, for example, Clostridium frigoris [48], the most abundant species in QUI samples (Table S4). Some nitrogen-assimilating microorganisms have been found in the glacial ice samples analyzed, especially in the eastern islands, for instance, Pseudomonas or Mycobacterium pinnipedii, which has been described as an infectious agent in seals [49]. Nitrification in these glaciers is performed by bacteria as Nitrosococcus and Nitrosovibrio (ammonia-oxidation) followed by oxidation of nitrite to nitrate carried out by Nitrobacter. These aforementioned microorganisms (especially Pseudomonas) and some others (Rhizobium, Enterobacter), which are also frequent in the islands with penguins, participate very actively in the phosphorus cycle. Regarding microeukaryotes, the flagellate Heteromita was very abundant in all samples. This protist has been shown to affect the bacterial community and to excrete ammonia as a main form of nitrogen [50]. It has also been reported that diatoms in dark and anoxic environments might be involved in anaerobic nitrate respiration [51]. The most abundant eukaryotic genus in ECO samples was Sporobolomyces (Table S4); this yeast produces a constitutive nitrate reductase and can use nitrate as the sole nitrogen source. The obtained nitrite is in turn reduced and assimilated by the yeast [52].

The microorganisms that participate in the sulfur cycle have been identified mainly in the vicinity of the volcano, forming a gradient of abundance that begins on Deception Island and goes east (Figure S3). Some of the most abundant species identified in this gradient were Sulfobacillus yellowstonensis, Desulfosporosinus meridiei, Desulfurispora thermophila, and Desulfotomaculum thermoacetoxidans. Additionally, several species of the Thiomonas and Thiobacillus genera were identified in the glaciers of Deception Island. These bacteria oxidize hydrogen sulfide to sulfur and sulfate, a key nutrient for microalgae, which enables the presence of these microeukaryotes and their predator protists in glacial ice. The bacterium, Paracoccus, identified in the eastern glaciers is capable of oxidizing reduced sulfur compounds. In general, the microorganisms that participate in the sulfur cycle are those that best fit the volcanic gradient. Figure S4 represents the abundance of the main bacterial species participating in the sulfur cycle along the volcanic gradient. If these microorganisms involved in the sulfur cycle have indeed spread throughout the archipelago South Shetland as a result of the explosive volcanic eruptions is an appealing question to investigate. It can be observed that the abundance of these microorganisms is greater in the glaciers closest to the volcano and decreases with distance. Microorganisms along aerosol gradients have been widely studied [53]. Several emission sources and short- to long-distance dispersal have been identified. Among them, volcanoes have the capability to load the troposphere and stratosphere with ash and microorganisms and affect long-distance transport rates on a global scale. For example, Bacillus luciferensis, was firstly identified from a sample collected at an altitude of $20 \mathrm{~km}$ that had been dispersed by an explosive volcanic eruption [54]. This aerial transport has also been reported for other species of viable bacteria and fungi in several reports $[55,56]$. 
The iron cycle in glacier samples was represented by $\mathrm{Fe}^{3+}$ reducer bacteria as Carboxydocella ferrireducens or Thermovenabulum ferriorganovorum, which are also capable of reducing sulfite, thiosulfate, and elemental sulfur $[57,58]$. Some identified oxidizers of $\mathrm{Fe}^{2+}$ were Ferrimicrobium and Gallionella ferruginea. There are few eukaryotic microorganisms involved in the iron cycle, although some protists such as Chlamydomonas sp. are resistant to high concentrations of metals [59]. Other microorganisms that participate in unusual biogeochemical cycles typical of volcanic areas, for example, selenium metabolizing microorganisms, were also found in ice samples from Deception Island (i.e., Selenomonas infelix) [60].

\section{Conclusions}

Our research shows that (i) in the studied South Shetland glaciers, great diversity was observed when compared with microbiomes of other Antarctic glaciers or frozen deserts; (ii) the communities of microorganisms were isolated from small clusters within the ice. Even the compositions of the microbial populations identified in the glaciers from the same island were different; (iii) most of the 16S and 18S rRNA sequences searched in the databases were identified as "Unclassified" OTUs. There is still a huge work to be done in researching environmental microorganisms in polar environments; (iv) englacial microorganisms play an important role in the glacial microbiome since they participate in the biogeochemical cycles of the ecosystem; (v) there is a correlation between the chemical composition of the glacial ice and the composition of the microbial communities along the volcanic gradient. The bacteria that take part in the sulfur cycle are those that best fit the volcanic gradient; (vi) the eastern islands are those that suffer the greatest human pressure and their glaciers contain microorganisms typical of this contamination (Enterobacteriaceae, Helicobacter); (vii) some microorganisms, for example, photosynthesizers, raise the question of whether they live in the englacial zone or they have been dragged from the upper layers of the glacier. Future studies should check whether they are metabolically active and study their mechanisms of adaptation using transcriptomic and proteomic techniques; (viii) lastly, glaciers and especially those in volcanic regions such as Iceland or the Deception Island in Antarctica are being widely studied as models for astrobiological exploration; the results of this work can expand the settings in which life might be possible.

Supplementary Materials: The following are available online at https:/ /www.mdpi.com/2076-260 7/9/2/392/s1, Table S1: Elemental concentrations in melt water, Table S2: Analysis of 16S rRNA, Table S3: Analysis of 18S rRNA, Table S4: Number of sequences belonging to the most abundant OTU in each sampling point, Figure S1: Rarefaction curves determined for 16S rRNA and 18S rRNA gene clones, Figure S2: Number of bacterial and microeukaryote sequences along the volcanic gradient, Figure S3: Examples of human and animal-derived bacteria and microeukaryotes in the glacier samples, Figure S4: The most abundant bacterial species participating in the sulfur cycle along the volcanic gradient.

Author Contributions: C.C. and L.G.-D. conceived and planned the experiments; C.C. and L.G.-D. performed field sampling; E.G.-L., S.S., M.A.C., S.P.P., and S.S.-C. Performed lab work and data acquisition; C.C. and E.G.-L. wrote, revised, and edited the manuscript; C.C. managed the acquisition of funds. All authors have read and agreed to the published version of the manuscript.

Funding: This research has been funded by the Spanish State Research Agency (AEI) Projects No. PID2019-104205GB-C22 and MDM-2017-0737 CAB (CSIC-INTA), Unidad de Excelencia María de Maeztu. Eva Garcia-Lopez is recipient of a Fellowship (PTA2016-12325-I). This research is part of POLARCSIC activities.

Institutional Review Board Statement: Not applicable.

Informed Consent Statement: Not applicable.

Data Availability Statement: Sequences obtained from 16S and 18S rRNA sequencing were deposited in NCBI Short Read Archive (SRA). 
Acknowledgments: We are indebted to Maria Paz Martin-Redondo from CAB for the ICP-MS analysis. We thank Paula Alcazar for reading this manuscript and for her helpful suggestions and revisions. We thank also the staff of the Spanish Antarctic Research Stations Gabriel de Castilla and Juan Carlos I, the Ecuadorian Research Station Pedro Vicente Maldonado, and the Polish Research Station Henryk Arctowski for their skillful assistance.

Conflicts of Interest: The authors declare no conflict of interest.

\section{References}

1. Sáez, P.L.; Cavieres, L.A.; Galmés, J.; Gil-Pelegrín, E.; Peguero-Pina, J.J.; Sancho-Knapik, D.; Vivas, M.; Sanhueza, C.; Ramírez, C.F.; Rivera, B.K.; et al. In situ warming in the Antarctic: Effects on growth and photosynthesis in Antarctic vascular plants. In situ warming in the Antarctic: Effects on growth and photosynthesis in Antarctic vascular plants. New Phytol. 2018, 218, 1406-1418. [CrossRef]

2. Sancho, L.G.; Pintado, A.; Navarro, F.; Ramos, M.; De Pablo, M.A.; Blanquer, J.M.; Raggio, J.; Valladares, F.; Green, T.G.A. Recent warming and cooling in the Antarctic Peninsula region has rapid and large effects on lichen vegetation. Sci. Rep. 2017, 7, 5689. [CrossRef]

3. Garcia-Lopez, E.; Cid, C. Glaciers and Ice Sheets as Analog Environments of Potentially Habitable Icy Worlds. Front. Microbiol. 2017, 8, 1407. [CrossRef] [PubMed]

4. Christner, B.C.; Mosley-Thompson, E.; Thompson, L.G.; Reeve, J.N. Isolation of bacteria and 16S rDNAs from Lake Vostok accretion ice. Environ. Microbiol. 2001, 3, 570-577. [CrossRef] [PubMed]

5. Antony, R.; Krishnan, K.P.; Laluraj, C.M.; Thamban, M.; Dhakephalkar, P.K.; Engineer, A.S.; Shivaji, S. Diversity and physiology of culturable bacteria associated with a coastal Antarctic ice core. Microbiol. Res. 2012, 167, 372-380. [CrossRef] [PubMed]

6. Knowlton, C.; Veerapaneni, R.; D'Elia, T.; Rogers, S.O. Microbial analyses of ancient ice core sections from Greenland and antarctica. Biology 2013, 2, 206-232. [CrossRef]

7. Miteva, V.I.; Sheridan, P.P.; Brenchley, J.E. Phylogenetic and physiological diversity of microorganisms isolated from a deep greenland glacier ice core. Appl. Environ. Microbiol. 2004, 70, 202-213. [CrossRef]

8. Katayama, T.; Tanaka, M.; Moriizumi, J.; Nakamura, T.; Brouchkov, A.; Douglas, T.A.; Fukuda, M.; Tomita, F.; Asano, K. Phylogenetic analysis of bacteria preserved in a permafrost ice wedge for 25,000 years. Appl. Environ. Microbiol. 2007, 73, 2360-2363. [CrossRef]

9. Shen, L.; Liu, Y.; Wang, N.; Jiao, N.; Xu, B.; Liu, X. Variation with depth of the abundance, diversity and pigmentation of culturable bacteria in a deep ice core from the Yuzhufeng Glacier, Tibetan Plateau. Extremophiles 2018, 22, 29-38. [CrossRef]

10. Anesio, A.M.; Laybourn-Parry, J. Glaciers and ice sheets as a biome. Trends Ecol. Evol. 2012, 27, 219-225. [CrossRef]

11. Hodson, A.; Anesio, A.M.; Tranter, M.; Fountain, A.; Osborn, M.; Priscu, J.; Laybourn-Parry, J.; Sattler, B. Glacial ecosystems. Ecol. Monogr. 2008, 78, 41-67. [CrossRef]

12. Cameron, K.A.; Hodson, A.J.; Osborn, A.M. Structure and diversity of bacterial, eukaryotic and archaeal communities in glacial cryoconite holes from the Arctic and the Antarctic. FEMS Microbiol. Ecol. 2012, 82, 254-267. [CrossRef]

13. Cook, J.; Edwards, A.; Takeuchi, N.; Irvine-Fynn, T. Cryoconite: The dark biological secret of the cryosphere. Prog. Phys. Geogr. Earth Environ. 2016, 40, 66-111. [CrossRef]

14. Martinez-Alonso, E.; Pena-Perez, S.; Serrano, S.; Garcia-Lopez, E.; Alcazar, A.; Cid, C. Taxonomic and functional characterization of a microbial community from a volcanic englacial ecosystem in Deception Island, Antarctica. Sci. Rep. 2019, 9, 12158. [CrossRef] [PubMed]

15. Fernandez-Turiel, J.L.; Saavedra, J.; Ruggieri, F.; Gimeno, D.; Perez-Torrado, F.J.; Rodriguez-Gonzalez, A.; Martinez, L.D.; Gil, R.; Garcia-Valles, M.T.; Polanco, E.; et al. Geoquímica de cenizas volcánicas a lo largo de dos transectas en Sudamérica: Implicaciones ambientales. Geo Temas 2012, 13, 1576-5172.

16. Baker, P.E.; Mcreath, I.; Harvey, M.R.; Roobol, M.; Davies, T.G. The geology of the South Shetland Islands. In Volcanic Evolution of Deception Island; British Antarctic Survey Scientific Reports: Cambridge, UK, 1975; p. 81.

17. Tin, T.; Fleming, Z.L.; Hughes, K.A.; Ainley, D.G.; Convey, P.; Moreno, C.A.; Pfeiffer, S.; Scott, J.; Snape, I. Impacts of local human activities on the Antarctic environment. Antarct. Sci. 2009, 21, 3-33. [CrossRef]

18. Power, M.L.; Samuel, A.; Smith, J.J.; Stark, J.S.; Gillings, M.R.; Gordon, D.M. Escherichia coli out in the cold: Dissemination of human-derived bacteria into the Antarctic microbiome. Environ. Pollut. 2016, 215, 58-65. [CrossRef] [PubMed]

19. Christner, B.C.; Mikucki, J.A.; Foreman, C.M.; Denson, J.; Priscu, J.C. Glacial ice cores: A model system for developing extraterrestrial decontamination protocols. Icarus 2005, 174, 572-584. [CrossRef]

20. Garcia-Descalzo, L.; Garcia-Lopez, E.; Postigo, M.; Baquero, F.; Alcazar, A.; Cid, C. Eukariotic microorganisms in cold enviroments: Examples from Pyrenean glaciers. Front. Microbiol. 2013, 4, 55. [CrossRef]

21. Garcia-Lopez, E.; Rodriguez-Lorente, I.; Alcazar, P.; Cid, C. Microbial communities in coastal glaciers and tidewater tongues of Svalbard Archipelago, Norway. Front. Mar. Sci. 2019, 5, 512. [CrossRef]

22. Garcia-Lopez, E.; Moreno, A.; Cid, C. Microbial community structure and metabolic networks in polar glaciers. In MetagenomicsBasics, Methods and Applications; InTech: London, UK, 2018. [CrossRef]

23. Edgar, R.C.; Haas, B.J.; Clemente, J.C.; Quince, C.; Knight, R. UCHIME improves sensitivity and speed of chimera detection. Bioinformatics 2011, 27, 2194-2200. [CrossRef] 
24. Raup, D.M. Taxonomic diversity estimation using rarefaction. Paleobiology 1975, 1, 333-342. [CrossRef]

25. Tipper, J.C. Rarefaction and rarefiction-the use and abuse of a method in paleontology. Paleobiology 1979, 5, 423-434. [CrossRef]

26. Šmilauer, P.; Lepš, J. Multivariate Analysis of Ecological Data using Canoco 5; Cambridge University Press: Cambridge, UK, 2014. [CrossRef]

27. Daher, M.; Schaefer, C.; Thomazini, A.; Neto, E.; Souza, C.; Lopes, D. Ornithogenic soils on basalts from maritime Antarctica. CATENA 2019, 173, 367-374. [CrossRef]

28. Ruggieri, F.; Fernandez-Turiel, J.L.; Saavedra, J.; Gimeno, D.; Polanco, E.; Naranjo, J.A. Environmental geochemistry of recent volcanic ashes from Southern Andes. Environ. Chem. 2011, 8, 236-247. [CrossRef]

29. Cámara, B.; Suzuki, S.; Nealson, K.H.; Wierzchos, J.; Ascaso, C.; Artieda, O.; de los Ríos, A. Ignimbrite textural properties as determinants of endolithic colonization patterns from hyper-arid Atacama Desert. Int. Microbiol. 2014, 17, 235-247. [CrossRef] [PubMed]

30. Durán, P.; Barra, P.J.; Jorquera, M.A.; Viscardi, S.; Fernandez, C.; Paz, C.; Mora, M.L.; Bol, R. Occurrence of Soil Fungi in Antarctic Pristine Environments. Front. Bioeng. Biotechnol. 2019, 7, 28. [CrossRef]

31. Butinar, L.; Spencer-Martins, I.; Gunde-Cimerman, N. Yeasts in high Arctic glaciers: The discovery of a new habitat for eukaryotic microorganisms. Antony van Leeuwenhoek 2007, 91, 277-289. [CrossRef]

32. Madigan, M.T.; Martinko, J.M.; Stahl, D.A.; Clark, D.P. Brock Biology of Microorganisms, 13th ed.; Pearson Education, Inc.: San Francisco, CA, USA, 2012.

33. Grzesiak, J.; Żmuda-Baranowska, M.; Borsuk, P.; Zdanowski, M. Microbial community at the front of Ecology Glacier (King George Island, Antarctica): Initial observations. Pol. Polar Res. 2009, 30, 37-47.

34. Lee, C.K.; Barbier, B.A.; Bottos, E.M.; McDonald, I.R.; Cary, S.C. The Inter-Valley Soil Comparative Survey: The ecology of Dry Valley edaphic microbial communities. ISME J. 2012, 6, 1046-1057. [CrossRef]

35. Kozubal, M.; Macur, R.; Jay, Z.; Beam, J.; Malfatti, S.; Tringe, S.; Kocar, B.; Borch, T.; Inskeep, W. Microbial Iron Cycling in Acidic Geothermal Springs of Yellowstone National Park: Integrating Molecular Surveys, Geochemical Processes, and Isolation of Novel Fe-Active Microorganisms. Front. Microbiol. 2012, 3, 109. [CrossRef] [PubMed]

36. Kleinertz, S.; Christmann, S.; Silva, L.M.; Hirzmann, J.; Hermosilla, C.; Taubert, A. Gastrointestinal parasite fauna of Emperor Penguins (Aptenodytes forsteri) at the Atka Bay, Antarctica. Parasitol. Res. 2014, 113, 4133-4139. [CrossRef] [PubMed]

37. Molina-Montenegro, M.A.; Carrasco-Urra, F.; Acuña-Rodriguez, I.; Oses, R.; Torres-Diaz, C.; Chwedorzewska, K.J. Assessing the importance of human activities for the establishment of the invasive Poa annua in Antarctica. Polar Res. 2014, 33. [CrossRef]

38. Chwedorzewska, K.J.; Korczak, M. Human impact upon the environment in the vicinity of Arctowski Station, King George Island, Antarctica. Pol. Polar Res. 2010, 31, 45-60. [CrossRef]

39. Button, D.K.; Robertson, B.; Gustafson, E.; Zhao, X. Experimental and theoretical bases of specific affinity, a cytoarchitecture-based formulation of nutrient collection proposed to supercede the Michaelis-Menten paradigm of microbial kinetics. Appl. Environ. Microbiol. 2004, 70, 5511-5521. [CrossRef]

40. Gosink, J.J.; Woese, C.R.; Staley, J.T. Polaribacter gen. nov., with three new species, P. irgensii sp. nov., P. franzmannii sp. nov. and P. filamentus sp. nov., gas vacuolate polar marine bacteria of the Cytophaga-Flavobacterium-Bacteroides group and reclassification of 'Flectobacillus glomeratus' as Polaribacter glomeratus comb. nov. Int. J. Syst. Bacteriol 1998, 48, 223-235. [CrossRef]

41. Chakravarthy, S.K.; Srinivas, T.N.R.; Kumar, P.A.; Sasikala, C.; Ramana, C.V. Roseospira visakhapatnamensis sp. nov. and Roseospira goensis sp. nov. Int. J. Syst. Evol. Microbiol. 2007, 57, 2453-2457. [CrossRef]

42. Lu, X.; Gao, F.; Shao, C.; Hu, X.; Warren, A. Morphology, morphogenesis and molecular phylogeny of a new marine ciliate, Trichototaxis marina n. sp. (Ciliophora, Urostylida). Eur. J. Protistol 2014, 50, 524-537. [CrossRef] [PubMed]

43. Li, J.; Chen, X.; Xu, K. Morphology and Small Subunit rDNA Phylogeny of Two New Marine Urostylid Ciliates, Caudiholosticha marina sp. nov. and Nothoholosticha flava sp. nov. (Ciliophora, Hypotrichia). J. Eukaryot. Microbiol 2016, 63, 460-470. [CrossRef]

44. Jongman, R.H.G.; TerBraak, C.J.F.; Van Tongeren, O.F.R. Data Analysis in Community and Landscape Ecology; Cambridge University Press: Cambridge, UK, 1995. [CrossRef]

45. Kulk, G.; Buist, A.; van de Poll, W.H.; Rozema, P.D.; Buma, A.G.J. Size scaling of photophysiology and growth in four freshly isolated diatom species from Ryder Bay, western Antarctic peninsula. J. Phycol. 2019, 55, 314-328. [CrossRef]

46. Bråte, J.; Fuss, J.; Jakobsen., K.S.; Klaveness, D. Draft genome assembly and transcriptome sequencing of the golden algae Hydrurus foetidus (Chrysophyceae). F1000Research 2019, 8, 401. [CrossRef]

47. Park, S.W.; Hwang, E.H.; Park, H.; Kim, J.A.; Heo, J.; Lee, K.H.; Song, T.; Kim, E.; Ro, Y.T.; Kim, S.W.; et al. Growth of Mycobacteria on Carbon Monoxide and Methanol. J. Bacteriol. 2003, 185, 142-147. [CrossRef]

48. Barbosa, A.; Balagué, V.; Valera, F.; Martínez, A.; Benzal, J.; Motas, M.; Diaz, J.I.; Mira, A.; Pedrós-Alió, C. Age-Related Differences in the Gastrointestinal Microbiota of Chinstrap Penguins (Pygoscelis antarctica). PLoS ONE 2016, 11, e0153215. [CrossRef] [PubMed]

49. Cousins, D.V.; Bastida, R.; Cataldi, A.; Quse, V.; Redrobe, S.; Dow, S.; Duignan, P.; Murray, A.; Dupont, C.; Ahmed, N.; et al. Tuberculosis in seals caused by a novel member of the Mycobacterium tuberculosis complex: Mycobacterium pinnipedii sp. nov. Int. J. Syst. Evol. Microbiol. 2003, 53, 1305-1314. [CrossRef] [PubMed]

50. Murase, J.; Noll, M.; Frenzel, P. Impact of protists on the activity and structure of the bacterial community in a rice field soil. Appl. Environ. Microbiol. 2006, 72, 5436-5444. [CrossRef] 
51. Stief, P.; Kamp, A.; de Beer, D. Role of diatoms in the spatial-temporal distribution of intracellular nitrate in intertidal sediment. PLoS ONE 2013, 8, e73257. [CrossRef]

52. Sollai, F.; Zucca, P.; Rescignoa, A.; Dumitriu, E. Sporobolomyces salmonicolor as a tool for nitrate removal from wastewaters. Environ. Eng. Manag. J. 2012, 11, 1455-1460. [CrossRef]

53. Griffin, D.; Gonzalez-Martin, C.; Hoose, C.; Smith, D. Global-Scale Atmospheric Dispersion of Microorganisms. In Microbiology of Aerosols; Delort, A.-M., Amato, P., Eds.; Willey: Hoboken, NJ, USA, 2017. [CrossRef]

54. Van Eaton, A.R.; Harper, M.A.; Wilson, C.J. High-flying diatoms: Widespread dispersal of microorganisms in an explosive volcanic eruption. Geology 2013, 41, 1187-1190. [CrossRef]

55. Griffin, D.W. Terrestrial microorganisms at an altitude of 20,000 m in Earth's atmosphere. Aerobiologia 2004, 20, 135-140. [CrossRef]

56. Smith, D.J.; Griffin, D.W.; Schuerger, A.C. Stratospheric microbiology at $20 \mathrm{~km}$ over the Pacific Ocean. Aerobiologia 2010, 26, 35-46. [CrossRef]

57. Zavarzina, D.G.; Tourova, T.P.; Kuznetsov, B.B.; Bonch-Osmolovskaya, E.A.; Slobodkin, A.I. Thermovenabulum ferriorganovorum gen. nov., sp. nov., a novel thermophilic, anaerobic, endospore-forming bacterium. Int. J. Syst. Evol. Microbiol 2002, 52, 1737-1743. [CrossRef] [PubMed]

58. Hudman, J.F.; Glenn, A.R. Selenite uptake and incorporation by Selenomonas ruminantium. Arch. Microbiol. 1984, 140, 252-256. [CrossRef] [PubMed]

59. Cid, C.; Garcia-Descalzo, L.; Casado-Lafuente, V.; Amils, R.; Aguilera, A. Proteomic analysis of the response of an acidophilic strain of Chlamydomonas sp. (Chlorophyta) to natural metal-rich water. Proteomics 2010, 10, 2026-2036. [CrossRef] [PubMed]

60. Toshchakov, S.V.; Lebedinsky, A.V.; Sokolova, T.G.; Zavarzina, D.G.; Korzhenkov, A.A.; Teplyuk, A.V.; Chistyakova, N.I.; Rusakov, V.S.; Bonch-Osmolovskaya, E.A.; Kublanov, I.V.; et al. Genomic Insights into Energy Metabolism of Carboxydocella thermautotrophica Coupling Hydrogenogenic CO Oxidation with the Reduction of Fe (III) Minerals. Front. Microbiol. 2018, 9, 1759. [CrossRef] 